\begin{tabular}{rr} 
çağdaş & Yaratıcı Drama Dergisi 2015, 10(1), 39-50 \\
drama & www.yader.org \\
\hline
\end{tabular}

\title{
Yaratıcı Drama Yöntemi ile Okul Öncesi Dönem Çocuklarına Mesleklerin Tanıtılması
}

\author{
Saliha Pehlivan ${ }^{1}$ \\ Ö. Özlem Gökbulut ${ }^{2}$
}

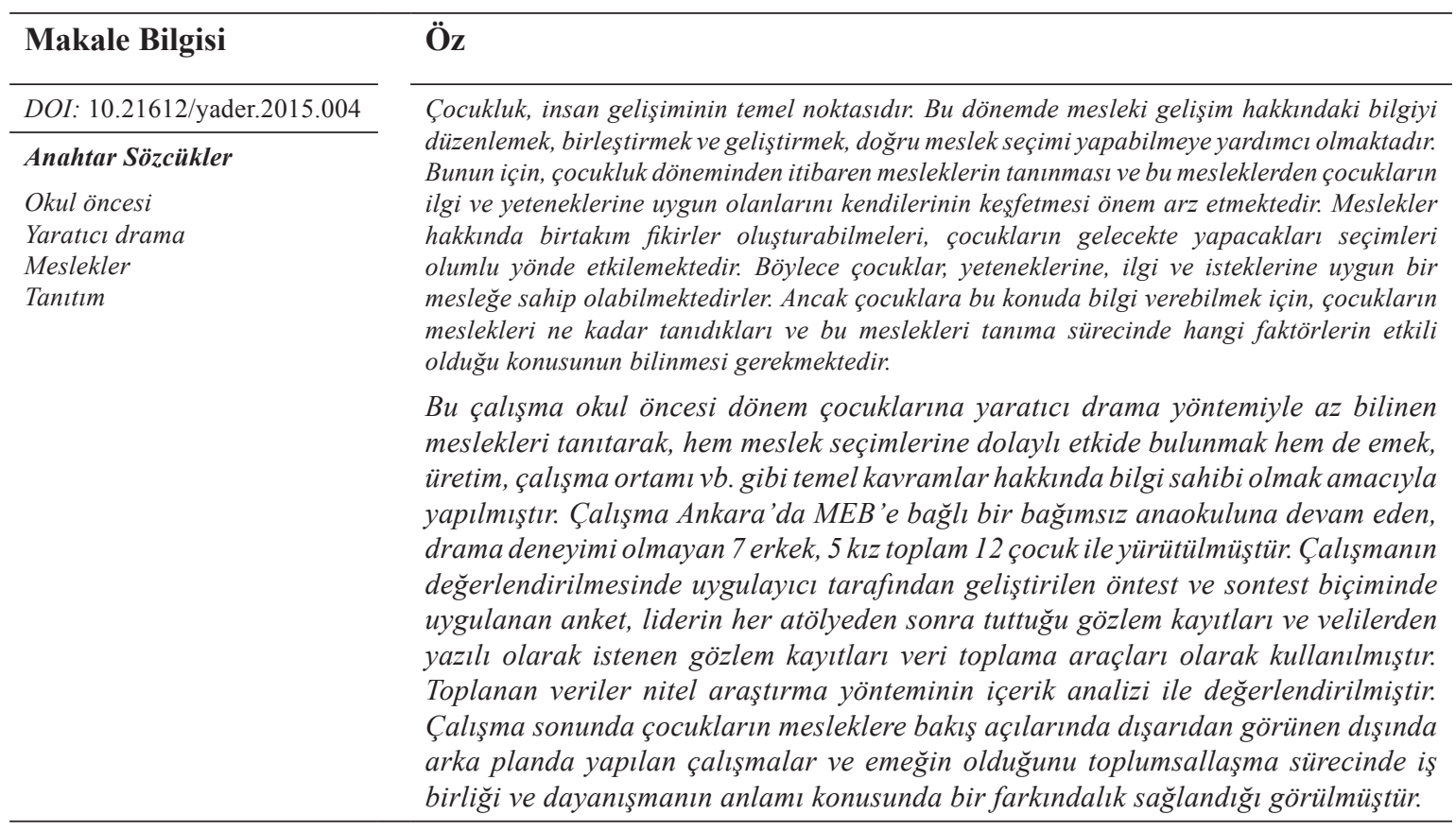

\section{Introducing Occupations to Preschool Children with the Creative Drama Method}

Article Info

DOI: 10.21612 yader.2015.004

Keywords

Preschool

Creative drama

Crafts

Promotion

\begin{abstract}
Childhood is the foundation of human development. During this period, combine and edit the information about professional development to develop, to make the right career choice can help. To do this, starting from the recognition of the profession from childhood and children's interests and capabilities of these professions as appropriate to discover their own importance. The children so that you can build a team ideas about occupations in the future will positively affect the elections. Thus children, attention and skills, can have a profession in accordance with the request. However, in order to provide information about the children, how many acquaintances and professions kids this is what factors in the process of effective recognition of professions that must be known.
\end{abstract}

This study children of preschool creative drama by introducing little-known professions, as well as the method of selection of the profession in the indirect effects as well as labor, production, working environment, such as basic concepts were made

1 Drama Lideri, E-posta: salihapehlivan80@hotmail.com

2 Bil. Uzm. Öğretmen, Milli Eğitim Bakanlığı. Eposta: oooozlemgokbulut@gmail.com 


\begin{abstract}
in order to be informed about. Working in Ankara for an independent nursery school connected to the ongoing Ministry of Education, drama experience non-7 male, were conducted with a total of 12 child 5 girls. The study was developed by practitioners in evaluating pretest and lasttest implemented in the form of a questionnaire, the leader after each workshop held in observation of the parents in writing requested registration and observation records as the data collection tools used. The collected data was evaluated using qualitative research method of content analysis. At the end of the working children are interested in occupations outside of externally visible in the background, perspective studies and is in the process of socialization of labor cooperation and provided an awareness about the meaning of solidarity was seen.
\end{abstract}

\title{
Giriş
}

Günümüzde, iş dünyası insan yaşamının merkezinde bulunmaktadır. Bu noktada bireylerin kendilerine uygun meslek seçimleri yapabilmeleri, daha mutlu ve sağlıklı olmalarını sağlayacak önemli bir koşul haline gelmektedir. Meslek bilgisi gelişimi, çocukluktan başlayan oldukça uzun bir süreci kapsamaktadır (Liben ve ark., 2001). Meslekler hakkında bir takım fikirler oluşturabilmeleri çocukların gelecekte yapacakları seçimleri olumlu yönde etkilemektedir. Böylece çocuklar, yeteneklerine, ilgi ve isteklerine uygun bir mesleğe sahip olabilmektedirler. Ancak çocuklara bu konuda bilgi verebilmek için, çocukların meslekleri ne kadar tanıdıkları ve bu meslekleri tanıma sürecinde hangi faktörlerin etkili olduğu konusunun bilinmesi gerekmektedir. Bu yolla elde edilen bilgiler çocukların ileriki yıllarda yapacakları meslek seçimlerini önemli ölçüde etkileyebilmektedir (Liben ve ark., 2001). Çocukların meslekler hakkında geliştirdikleri yargı ve fikirler bu mesleklere bakış açılarını etkilemekte ve bu bakış açılarına göre meslek seçimi yapmalarını sağlamaktadır. Çocukların meslekler konusunda doğru bilgi edinmeleri için meslekleri doğru tanımaları gerekmektedir.

Meslek, bireylerin hem toplumda bir yer edinme hem de bireysel ihtiyaçlarının karşılanması bakımından önemli bir yere sahiptir (Telman,1991). Bu yönüyle ele alındığında meslek aşağıdaki tanımlarla ifade edilmektedir.

Meslek kavramı; Türk Dil Kurumu Sözlüğü’nde “Belli bir eğitim ile kazanılan sistemli bilgi ve becerilere dayalı, insanlara yararlı mal üretmek, hizmet vermek ve karşılığında para kazanmak için yapılan, kuralları belirlenmiş iş" olarak tanımlanmaktadır.

Kuzgun (2002), "İnsanın bilgi, beceri doğrultusunda öğrenme yolu ile veya ustalık kazandı̆̆1 ve bir ödül karşılığ1 yaptığı faaliyetler toplamı” (Özgüven, 2000); "Bir kimsenin yaşamını sürdürmek, geçimini sağlamak için seçtiği sürekli iş alanı” olarak tanımlamaktadır.

Mesleki gelişim süreci, bedensel, zihinsel, sosyal, duygusal ve bilişsel gelişmelerle çok yakından ilişkilidir. Meslek daha küçük yaşlarda başlayıp ilerleyen yaşlarda somutlaşır. Çocuk büyüyüp öğrendikçe yeni ilgi alanları geliştirmekte bazı alanlardaki ilgilerini de derinleştirmektedir. Yaşadıkça, öğrendikçe yeni tecrübe ve beceriler kazanarak çevresindeki yetişkinleri gözlemektedir. Geliştirdiği yeni fiziksel ve bilişsel becerilerden hayatında nasıl yararlanması gerektiğini öğrenmektedir. Bunlar, meslek kavramının ve ihtiyacının gelişmesinde temel başlangıçtır ve meslek gelişiminin süreçlerini oluşturmaktadır (Tan, 2000, s.123).

Mesleki gelişim süreci, çocuklukta bir meslek fikrinin oluşmaya başlamasından, yetişkinlikte bir meslek sahibi oluncaya kadar geçen gelişim evrelerini kapsar. (Yeşilyaprak, 2003). Meslek gelişim süreci günümüzde okul öncesi yıllardan başlayan bir süreçle ele alınmaktadır. Çocuğun ve daha sonra ergenin gelişim özellikleri ve bilişsel yapısına da uygun olarak değerlendirilen bireye ve çevresine 
ait birçok etmenin etkileşimi ile oluşan mesleki gelişim süreci aşamalarından biri olan "Uyanış ve farkında olma", okul öncesi dönemden başlayarak ilkokul sonlarına kadar devam eden bir dönemdir. Dönemin başlarında çocuk, çevresindeki meslekleri fark ederek, bireylerin farklı mesleklere sahip olduklarını kavrar.

Benjamin S.Bloom (1979) "İnsan Nitelikleri ve Okulda Öğrenme” isimli eserinde; her çocuğun zeka gelişiminin \%50'sinin 0-4 yaş arasına, \%30'unun 4-8 yaş arasına, \%20'sinin ise 8-18 yaşlar arasına rastladığını" ortaya koyar. Bu nedenle zeka gelişiminin büyük yüzdesine sahip olan evre olan okul öncesi dönemi, çocukların sağlıkla geçirmesi ve üzerinde durulması gereken çok önemli bir devredir (Öztürk, 2010).

Gelişim evrelerinden olan bilincin oluştuğu, 4 yaştan başlayıp 14 yaşa kadar süren ve çocukluk olarak adlandırılan bu dönem; fiziksel, psikolojik ve sosyal bakımdan en hızlı gelişimin olduğu dönemdir. Çocuk, yetişkinlerin rollerini izlemekte ve onlara benzeme arzusu ile hayalinde bir takım mesleklere özenmektedir. Çocukların mesleklere olan bakış açıları; aile, medya, çevre ve akran gruplarının etkileriyle şekillenmektedir.

Dönemin sonlarında ise çocuk kendisi ile diğer insanlar arasında ilgiler, yetenekler, amaçlar ve motivasyon yönünden farklılıkları ve benzerliklerin farkına varmaya başlar (Yeşilyaprak, 2005). $\mathrm{Bu}$ farkındalığı elde ettiği en etkili ve kolay yollardan birisi oyundur. Çocuk özellikle dramatik oyun oynarken çeşitli mesleklerin rollerini üstlenir ve yetişkinleri taklit eder. Çocuğun hayal gücüne ve gözlemlerine bağlı olarak üstlendiği roller değişmektedir. Çocuk, kendi özelliklerinin farkına varmadan ve bunları düşünmeden, mesleklerin özelliklerini değerlendirmeden meslek seçimlerini rol modelleri ile sınırlandırır ve bu işin sorumluluğunu alır. Aslında oyunlarla kendini bir işin içinde bulur yani ilk işi oyundur. Bu dönemde oynanan oyunlar zihinsel yetenekleri kadar, tüm gelişim alanlarını uyaran, duygularını ve duyularını geliştiren etkinliklerdir.

Montaigne, "Çocuğun en ciddi uğraşı oyun, en önemli işi oyundur"; Gross, "Gerçek hayata hazırlayan alıştırmalardır"; Montessori, "Çocuğun işidir”; Freud, "Korkuların engellenmesinin ve sosyal çatışmanın üstesinden gelme yoludur” ifadeleriyle oyunu tanımlarlar (Öztürk, 2010).

En geniş anlamıyla oyun, belli bir amaca yönelik olan veya olmayan, kuralı ya da kuralsız olarak gerçekleştirilebilen, her durumda çocuğun isteyerek ve hoşlanarak yer aldığı, fiziksel, bilişsel, dilsel, duygusal ve sosyal gelişimin temeli olan, gerçek hayatın bir parçası ve çocuk için en etkin bir öğrenme süreci şeklinde tanımlanır (Öztürk, 2010).

Oyun yoluyla çocuk gelecekteki rollerini deneyimler. Özellikle dramatik oyunlarda çocuk, yetişkin yaşantısını taklit ederken, gerçek yaşantısında yer alacak deneyimler kazanır. Oyun, çocuğun yaratma ortamıdır. Çocuk tüm konuşma kabiliyetini, düşünme ve ortaya koyma yeteneğini, tecrübe haznesini, gözlem yeteneğini oyunla sergiler. Çocuk, yalnız büyüklerden öğrendiğini ve gördüğünü oyuna aktarmakla kalmaz, kendi yeteneklerini de bunlara katarak yeni şeyler yaratır. Oyun, çocuğu gerçek hayata hazırlayıcı etkin bir araçtır.

Çocuk, oyun aşamalarında, hoşlandığı veya hoşlanmadığı etkinliklerin farkına varır. Kendini ilgileri açısından değerlendirmeye başlar. Yeteneklerinin farkına vararak mesleklerle yetenekleri arasında ilişki kurar. Değerlerin bilincine varır; kendi değerleri, toplumun ve mesleklerin değerlerini fark eder.

Bazı çocuklar daha hareketli aktif meslekleri oynamaktan hoşlanır, kimi çocuklar ise daha sakin meslekleri seçer, örneğin bazı çocuklar terzi olup dikiş dikerken ya da yemek yapıp aşçı olmak 
isterken diğer çocuklar polis olup suçluyu yakalamak ister ya da pilot olup uçmak ister. Çocuğun kendi ilgi duyduğu alanları keşfetmesi, yaşamının ilk yıllarında başlar.

Meslek seçiminde ailenin rolü de oldukça önemlidir çünkü; ana-babaların çocuklarının küçük yaştan itibaren yeteneklerini dikkate alarak bu yönde onları desteklemeleri ve aldıkları kararlara saygı duyup onları kabullenmeleri gerekmektedir.

Roe, çocukluk yaşantılarını incelerken özellikle, ana-babaların çocuklarına karşı tutumlarını esas belirleyici olarak almış ve ana-baba ile çocuk ilişkilerinin farklı mesleki seçimlere neden olduğunu ileri sürerek üç aşamada konuyu ele almıştır (Yeşilyaprak, 2005).

Çocuğun üzerine aşırı düşmek, onun kendi başına yaşantılar kazanmasını ve bağımsız bir kişilik geliştirmesini engeller. Çocuğa soğuk davranarak, başkalarına karşı saldırgan bir tutum ya da saldırgan eğilimler geliştiren çocuklar yetiştirebilirler. Kabul edici ebeveynlerin çocukları, meslek seçerken savunucu olmayan bir tutumla daha özgür olarak yeteneklerini sergileyebilecekleri meslekleri seçerler. Meslek seçimi, insanın hayatında aldığı en önemli kararlardan biridir. Seçtiğimiz meslek, keyifle ve severek yaptığımız sürece ardından başarının gelmesi de kaçınılmazdır ve bireylerin daha mutlu bir yaşam elde etmesini sağlar Ancak kişi yanlış meslek seçerse başarısızlık, mutsuzluk ve ardından depresyonun gelmesi de ne yazık ki kaçınılmaz olur. Toplumun mutlu ve başarılı bireylerden oluşması için kişinin kendi yeteneklerine göre, ilgi duyduğu alanlarda meslek seçmesi mutlu bir yaşam için olması gerekendir. Kişiler kendi yeteneklerini ve ilgilerini çocukluk döneminde oyun yoluyla anlayıp öğrenmeye başlar.

Çocukların doğalında oynadığı dramatik oyun ve diğer oyunların yanı sıra onarla rehberlik etmek isteyen yetişkinlerin etkin olarak kullandığı oyunlardan da etkin biçimde yararlanan alan yaratıcı dramadır. Yaratıcı drama, kurgusal ortamda gerçek yaşamın hepsini deneyimleme olanağı sağlamasıyla aktif öğrenme yöntemlerinin de en başında gelmektedir

Yaratıcı drama, çocuğu merkeze alarak onun öğrenme sürecine aktif olarak katılmasını sağlamaktadır. Aktif öğrenmenin gerçekleştirildiği yaratıcı drama sayesinde çocuklar yaratıcı, eleştirel, çok boyutlu ve özgürce düşünebilmekte; bilişsel, sosyal, duygusal, psikomotor yönden gelişim göstermekte, eğlenmekte, empati kurabilmekte, bildiklerini hayata geçirebilmekte ve işbirliği yapma becerilerini geliştirebilmektedir. Çocukların bir grubun üyesi olmaları, onların toplumunun birer üyesi olduklarını düşünmelerini dolayısıyla toplumdaki değerlerden haberdar olmalarını sağlamaktadır. Çocukların etkin olduğu bu süreçte birbirleriyle ve grup içindeki arkadaşlarıyla etkileşime girdiklerinde kendileriyle barışı hale geldikleri, cesaretlendikleri ve kendilerine daha çok güvendikleri bilinmektedir

Eğitimde sözel ve sembolik ağırlıklı öğrenimin yerini görsel ve yaşantılara dayalı öğretim almaktadır. Çünkü bireyde kalıcı öğrenmenin olabilmesi için etkin katılım gerekmektedir. Sözel ağırlıklı öğretimde $\% 10$ olan hatırlama ve kalıcılık görselde $\% 30$, yaşantılara dayalı öğretimde \%90'a ulaşmaktadır. (Demirel, 2005, s.57). Ulutaş (2011, s.234), dramanın kapsamının altı maddeyle açıklanabileceğini öne sürmüştür:

1. Çocuk dramayla anlamlı içeriği öğrenir.

2. Öğrenme, drama sırasında çocuğunv çevreyle etkileşmesi sonucunda gerçekleşir.

3. Çocuk drama sırasında duyu organlarını çokça kullanmaktadır.

4. Çocukların en iyi şekilde öğrenmeleri, yaparak ve yaşayarak öğrenme yoluyla gerçekleşmektedir. 
5. Uyarıcının fazla olduğu drama sürecinde öğrenme daha kolay ve kalıcı olmaktadır.

6. Dramadaki aktif katılım, duygusal öğrenmede çok önemlidir.

Dorothy Heathcote (1984)'a göre yaratıcı drama; öğrenmek, sahneye çıkmadan ve oyunda rol yapmadan yaşam deneyimini genişletmek demektir. Ona göre drama, bir öğrenme, bir bilgi edinme arac1, gerçekliğin varlığı içinde yansıtıcı unsurları yaratma sürecidir. Heathcote, eğitimde dramayı karakterlerde değil davranışlarda hayat temelli var olan şeyler ve bu aracın doğal kanunları olarak niteler. Yaratıcı drama; motive edici ve eğitsel bir yöntem, bir tür yaşam pratiği, oyuna dayalı bir tür grup çalışmasıdır (Adıgüzel, 2012, s.60).

Yaratıcı drama çalışması, oyun yoluyla her yaştaki kişiye uygulanarak kişinin gelişimini etkili biçimde sağlar. Dorothy Heathcote'un vurguladığı gibi drama; hem yaşama meydan okumadır hem yaşamın kendisidir hem de yaşama tam bir hazırlık niteliği taşır.

Eğitimde yaratıcı drama, özellikle okullardaki çeşitli öğrenim basamaklarında çocuğa kendini tanımayı, yeti ve yeteneklerini keşfetmeyi, grup arkadaşlarını yani başkalarını da tanımayı, kendini onların yerine koyabilmeyi, bir olgu ya da çeşitli yönleriyle irdelemeyi, oynayarak, yaşayarak öğrenmeyi sağlamaktadır (San,1991, s.262).

Aşırı ussal, ezbere yönelik, aşırı bilgi yüklü, okul yaşamından zevk almaya yönelmeyen, öğrenmenin duyuşsal, sezgisel yanını savsaklayan, öğrencinin yaşayarak öğrenip kendi sentezlerine varamadığı bir eğitim anlayışı, yetiştirmek durumunda olduğu çağdaş insanın gereksinimlerini karşılayamaz (San,1991 s.2).

Yaratıcı drama da konu-tema herhangi bir olay, olgu, soyut-somut bir durum, bir gazete haberi, bir karikatür, yazının (edebiyatın) tüm türleri, yarım bırakılmış herhangi bir edebi metin, bir yaşantı, bir anı, fotoğraf olabilir. Bir ders konusu, yaratıcı dramada işlenecek konuyu rahatlıkla oluşturabilir (Adıgüzel, 2006, s.24).

Bireyin kendine özgü niteliklerini, ilgi ve yetenekleri doğrultusunda tanımada etkili bir yöntem olan yaratıcı drama, aynı zamanda bireyin kendisini de tanımasını sağlayacaktır. Yaratıcı drama etkinlikleri, özellikle doğaçlamalar, çeşitli mesleklerin farklı bakış açıları ile tanıtılması, avantaj ve dezavantajlarımızın değerlendirilmesini ilgi ve mesleklere ilişkin toplumun yaklaşımının ortaya çıkmasını sağlar (Süner, 2008, s.59).

$\mathrm{Bu}$ doğrultuda eğitimde, öğrencilere yaşayarak öğretme ve öğrenme olanağını tanıyan yaratıcı dramayı bir yöntem olarak kullanabiliriz. Yaratıcı drama yöntemi ile öğrencilere meslekleri tanıtırken hem yeteneklerini, ilgilerini hem de kendisini ve grubu tanıtma ve anlatma olanağını sağlamış oluruz. Toplumda çeşitli meslekler vardır ve hepsinin ayrı ayrı zor yanları vardır ama tüm bu meslekler ihtiyaçlarımızın sonucunda ortaya çıkmıştır. Çocuklar meslekleri tanırken, üretmenin zorluğu konusunda farkındalık kazanırken ve tüketirken daha özenli olması gerektiğini anlar.

\section{Yöntem}

\section{Araștırmanın Modeli}

Okul öncesi dönem çocuklarına meslekler hakkında fikir vermeyi amaçlayan bu çalışma, nitel bir çalışmadır. 


\section{Çalışma Grubu}

Proje, Toki Göksu Anaokulu'nda eğitim almakta olan dört yaşında 5 kız 7 erkek olmak üzere toplam 12 çocuk ile gerçekleştirilmiştir.

\section{Veri Toplama Araçları}

Proje süresince kullanılan veri toplama araçları; çocuklarla yapılan görüşmeler, çocukların yapmış olduğu resimler, meslekler hakkında öğrendikleri bilgilere yönelik veli mektupları ve öğretmen gözlem kayıtlarıdır.

\section{Verilerin Toplanması}

Çalışma kapsamında gerçekleştirilen atölye çalışmaları 12 gün sürmüş, her gün bir oturum şeklinde uygulanarak araştırmanın verileri atölye sürecinde toplanmıştır. Uygulama sürecinin dönütlerini belirlemek ve kazanımlara ulaşma düzeyini belirlemek amacıyla verilerin toplanması sürecinde veli görüşleri de çalışmaya dahil edilmiştir. Çalışma sürecinde çocuklarının meslekler hakkında fikir sahibi olup olmadığı ile ilgili görüşlerini almak amacıyla, velilerden çocuklarının mesleklerle ilgili paylaşımlarını mektup şeklinde yazmaları istenmiştir. Çalışma kapsamında tüm atölye süreci kayıt altına alınarak öğretmen atölye süresince yapmış olduğu gözlemler ve değerlendirmeleri düzenli olarak yazılı kayıt altına almıştır.

\section{Verilerin Çözümlenmesi}

Nitel veri toplama tekniklerinin kullanıldığı betimleyici bir araştırma olan bu çalışmada, ulaşılan verilere betimsel analiz yapılmış ve ulaşılan bulgular katılımcı görüşlerinden yapılan doğrudan alıntılar ile desteklenmiştir. Öğretmen gözlem kayıtlarıyla, atölyeler uygulanırken yaşanan olumlu ve olumsuz durumlar belirlenerek proje sonrasında neler yapıldığ 1 ve başka neler yapılabileceğiyle ilgili görüşler belirtilmiştir.

\section{Bulgular}

Meslekler hakkında okul öncesi dönem çocuklarının farkındalığını geliştirmeyi amaçlayan bu çalışma kapsamında ulaşılan bulgular, "Büyüyünce ne olacaksın?" sorusunun yanıtlarına ilişkin bulgular ile oturum gözlemlerine ilişkin bulgular olmak üzere iki başlık altında ele alınmıştır.

\section{“Büyücünce ne olmak istersin?” Sorusunun Yanıtlarına İlişkin Bulgular}

Atölye çalışmaları başlamadan önce çocukların hazır bulunuşluğunu ölçmek amacıyla uygulamadan önce ve projenin etkisini ölçmek için de uygulamadan sonra olmak üzere çocuklara iki kez “Büyüyünce ne olacaksın?” sorusu yöneltilerek iki yanıt arasındaki farklar değerlendirilmiştir.

Tablo 1. Büyüyünce ne olmak Istersin?

\begin{tabular}{lll}
\hline Çocuk & Ön Test & Son Test \\
\hline Çocuk 1 & Örümcek Adam & Apron \\
Çocuk 2 & Baba & Çilingir \\
Çocuk 3 & İşçi & Agronom \\
Çocuk 4 & Hırsız & Makinist \\
\hline
\end{tabular}




\begin{tabular}{|lll|}
\hline Çocuk 5 & Para Kazanmak & Apron \\
\hline Çocuk 6 & Polis & Polis ve Fırınc1 \\
\hline Çocuk 7 & Burger Kıngci & Burger Kıngci ve Agronom \\
\hline Çocuk 8 & Doktor & Doktor \\
\hline Çocuk 9 & Balerin & Balerin \\
\hline Çocuk 10 & Balerin & Balerin \\
\hline Çocuk 11 & Doktor & Doktor \\
\hline Çocuk 12 & Doktor & Doktor \\
\hline
\end{tabular}

Yaratıcı drama yöntemi ile 12 çocukla yapılan atölyeler sonucunda "Büyünce ne olacaksın?" sorusuna verdikleri cevaplarla 5 çocuğun yapmak istediği mesleği değiştirdiği belirlenmiş, 3 çocuk görüşmeler esnasında "çünkü daha önce ben bu mesleği bilmiyordum yeni öğrendim” ifadesi ile önceki mesleğinin yanında yeni öğrendiği mesleği de yapmak istediğini söylemiş, 4 çocuğun olmak istediği mesleğini değiştirmek istemediği görülmüştür.

\section{Oturumlara İlişkin Bulgular}

1. Oturum: "Grup arkadaşlarının isimlerini söyler.”, "Liderinin ismini söyler.", “Kendini farklı yollarla ifade eder." kazanımına yönelik yapılan gözlemler sonucunda; atölye çalışma esnasında çocukların arkadaşlarının isimlerini rahatlıkla öğrendiği ve aralarında hızlı bir kaynaşma olduğu görülmüştür. Öğrencilerin olmak istedikleri meslekleri içselleştirerek sessiz sinema oyunundan keyif aldıkları ve arkadaşları hakkında daha ayrıntılı bilgi edindikleri izlenmiştir.

2. Oturum: "Grup arkadaşları ile iletişim kurar.", "Etkinliklere istekli olarak katılır." kazanımlarına yönelik yapılan gözlemler neticesinde; çocuklar toplum içinde iletişimin, çevresinde yaşayan insanları küçümsemeden selam vermenin önemini kavramış ve etkinliklerin tamamında keyif alarak canlandırmalarda yer almışlardır.

3. Oturum: "Yardımlaşmanın önemini kavrar." kazanımına yönelik yapılan atölye sonucunda, çocukların atölyede sergilemiş oldukları tutum ve davranışları ile sorulara verdikleri cevaplardan yola çıkarak gözlem yapılmıştır. Bu atölyede, kutuyu sınıfa güçlükle getirip çocuklardan yardım istendiğinde tüm çocukların hiç tereddüt etmeden yardıma koştukları gözlenmiştir. Büyük ve süslü bir hediye paketi tüm çocukların dikkatini çekmiştir. Çocuklardan yardım istendiğinde hep birlikte sorunun üstesinden gelmek için çaba sarf ettikleri, kutuyu taşıma sirasında çok güçlü oldukları söylendiğinde ise daha hızlı taşımaya çalıştıkları görülmüştür. Çocukları yüreklendirerek, onlara güvenerek ve onlarla işbirliği içinde olunduğunda çocuklarda özgüven artış1 gözlenmiştir. Ayrıca kutunun içinde ne olduğu ve kuklanın ülkesine nasıl gideceği merakı ile yapmış oldukları işlerde çok daha aktif ve heyecanlı oldukları gözlenmiştir. Kuklanın size ihtiyacı var ona yardım etmek ister misiniz?, sorusuna tüm çocukların "evet, tabii ki yardım ederiz", cevaplarıyla "biz hep birlikte yapabiliriz, buna gücümüz var” mesajını verdikleri gözlenmiştir.

4. Oturum: "Makinistlik mesleği hakkında fikir sahibi olur." kazanımına yönelik yapılan çalışmalar sonucunda; Çocukların "Daha önce hiç trene bindiniz mi?" sorusuna verdiği cevaplardan 12 çocuktan 2 çocuğun trene bindiği öğrenilmiştir. "Daha önce hiç tren gördünüz mü? sorusuna verdikleri cevaplardan ise 12 çocuktan 4 tanesinin treni gördüğü, 2 çocuğun da televizyondan gördüğü anlaşılmıştır, "Ben hiç treni görmedim." diyenler çoğunluktadır. Çocukların verdikleri cevaplardan 
yola çıkarak gelişen teknoloji ile birlikte treni çok tanımadıkları gözlenmiştir. Canlandırma etkinliğinde çocuklardan çoğu diğerine "Sen makinist ol ben başka bir şey olmak istiyorum.", söylemleri dikkat çekmiş ve makinistlik mesleğinin çocukların ilgisini pek fazla çekmediği görülmüştür. Bu atölyede çocukların en çok tren oyunundan keyif aldıkları izlenmiştir. Bunun sonucunda ise içeriğinde daha çok hareket barındıran işlerin çocukların ilgilerini çektiği düşünülmektedir. Atölyenin sonunda "treni kim kullanır ya da makinist ne iş yapar?" sorularına çocuklardan gelen olumlu cevaplar sonucunda, tüm çocuklardan makinistin ne iş yaptığı konusunda olumlu dönütler alınmıştır.

5. Oturum: "Marangoz mesleği hakkında fikir sahibi olur" kazanımına yönelik çalışmalar sonucunda yapılan gözlemler neticesinde; bu atölyede çocukların tamamının aktif ve üretken oldukları gözlenmiştir. Tüm çocukların kendi çabaları ile üretmekten ve yaptıkları işleri sergilemekten keyif aldıkları izlenmiştir. Erkek çocukların ev yapmak için uğraşırken kız çocukların daha çok eşya yapmak için uğraştıkları, ayrıca erkek çocukların işlerinde zımparayı tercih edip kullanırken, kız çocukların ise sadece zımparaya bakıp onu inceledikleri görülmüştür. Erkeklerin daha fazla güç isteyen zor işlere, kızların ise daha kolay ama incelik isteyen işlere yöneldiği görülmüştür. Erkek çocukların marangozların kullandığı aletlerden en çok keseri ve testereyi tanıdığ 1 , kız çocukların ise aletleri tanımadıkları söylenebilir. Sınıfa getirilen talaş, tüm çocukların dikkatini çekmiş daha önce hiç bir çocuğun talaşı görmediği gözlenmiş ve talaşı yakından inceleme firsatı onlar için farklı bir deneyim olmuştur. Grupla birlikte kuklaya yardım etmek için istekli olarak çalıştıkları, yaptıkları işe sahip çıkarak onu önemsedikleri gözlenmiştir. Bundan hareketle, emek vererek yapmış oldukları ürünlerin kendilerince çok kıymetli ve anlamlı olduğu anlaşılmıştır. Arkadaşlarının yapmış olduğu işlere saygı göstererek özenli davrandıkları ve yapmış oldukları işleri bozmamaya gayret gösterdikleri gözlenmiştir, bu bağlamda çocukların emeğe saygı bilincine vardıkları düşünülmektedir. Çember halinde sohbet sırasında marangozluk mesleğinin konuşularak anlatılmaya çalışıldığında tüm çocukların sıkıldığ 1 ve dikkatlerinin dağıldığı, ama uygulamaya geçildiğinde eğlenerek bu mesleği öğrendikleri gözlenmiştir. Çocukların marangozluk mesleği hakkında yaşayarak ve deneyimleyerek fikir sahibi oldukları, atölyenin sonundaki söylemlerinden ve yaptıklarından anlaşılmıştır.

6. Oturum: "Agronom mesleği hakkında fikir sahibi olur." kazanımına yönelik yapılan çalışmalar sonucunda Çocuklara sorulan sorularla toprağı araştıran kişinin bahçıvan ya da çiftçi olduğunu bildikleri ve Agronom kelimesini ise ilk defa duyduklarını bu mesleği daha önce hiç bilmediklerini söylemişlerdir. Atölyenin sonunda, çocukların yapmış olduğu resimlerden ve sohbet sırasındaki sorulara verilen cevaplardan hareketle, Agronom mesleği ile ilgili çizmiş oldukları toprak, tarla, ürün, çiçek objelerinden bu meslek hakkında fikir sahibi oldukları anlaşılmaktadır.

7. Oturum: "Çiftçilik mesleği hakkında fikir sahibi olur." kazanımına yönelik çalışmalar neticesinde, çocukların, "’Çiftçiler ne iş yapar kuklamız unutmuş siz biliyor musunuz?" sorusuna verdikleri cevaplarla diğer mesleklere oranla çiftçilik mesleği hakkında daha fazla bilgilerinin olduğu gözlenmiştir. Çocukların yabani ot, ürün, ilaçlama, solucan, gibi kelimeleri kullanmaları dikkat çekmiştir. Bu mesleği tanımalarında televizyon, çizgi film ve aile yaşantısının etkili olduğu kanısına varılmaktadır. Çocuklar kendileri ekip, biçip, üretmekten keyif almış, bunu da tüm atölye süresince aktif olarak yansıtmışlardır. Çocukların, "Gübre nedir, nasıl oluşur daha önce hiç duymuş muydunuz?" sorusuna verdikleri cevaplarla daha önce hiç gübreyi duymadıkları ve nasıl olduğu hakkında bilgilerinin olmadığı anlaşılmıştır. Hayvan pisliklerinin toprağın vitamin kaynağı olmasının çocukları çok şaşırttığı gözlenmiştir. Ayrıca çocukların tahılları çok tanımadığı, nasıl oluştuklarını 
bilmedikleri de verdikleri cevaplardan anlaşılmıştır. Çocuklar, tahıl ürünlerini daha çok marketten hazır aldıklarını söylemişlerdir. Sınıfa getirilen buğdayı merak içinde inceleyip başak resmi ile birlikte anlatıldığında nasıl oluştuğu hakkında da bilgi sahibi olmuşlardır. Ayrıca çocukların çiftçi çizmelerini görünce hemen yanına gelip dokunmak istemeleri, büyüklüğüne şaşırmaları, daha önce bu tür çizme görmedikleri ve bilmedikleri kanısını oluşturmuştur. Bu atölye sonunda çocukların; çiftçilerin ekip biçtiği, hayvanlara baktığı bilgilerinin yanı sıra ürünün son aşamasına gelinceye kadar neler yaptıkları, kışın hangi işleri yaptıkları, yazın ne iş yaptıkları hakkında fikir sahibi oldukları görülmüştür. Oyun oynarken gübre, başak, buğday, değirmen, ahır, kümes, yem gibi kelimeleri kullanmaları, anlamlarını sohbet sırasındaki söylemlerinden öğrendiklerini göstermektedir. Çember halinde sohbet ederken mesleğin konuşularak anlatılmaya çalışıldığında tüm çocukların sıkıldığı ve dikkatlerinin dağıldığı ama uygulamaya geçildiğinde eğlenerek meslekleri öğrendikleri gözlenmiştir.

8. Oturum: "Fırıncılık mesleği hakkında fikir sahibi olur." kazanımına yönelik çocukların verdiği geri bildirimlere aşağıda yer verilmiştir. Çocuklar "Siz hiç firıncı gördünüz mü, ne iş yaparlar?" sorusuna verdikleri cevaplarda daha çok “yemek yapar, pasta yapar” demişlerdir. Peki ekmekleri kim yapar?, sorusu yönelttiğin de ise çocukların ekmekleri marketten aldıkları ve nerde oluşup piştiğini bilmedikleri anlaşılmıştır. Bu atölyede çocukların tükettiği ürünlerin nerede satıldıklarını bildikleri, ancak nasıl yapıldığı ve üretim yerleri hakkında fikir sahibi olmadıkları kanısına varılmıştır. Atölye sırasında fırın resimleri ve hamur yoğurma teknesi resimleri çocukların dikkatini çekmiş, daha önce bunları görmediklerini söylemişlerdir. Bu uygulama sonucunda, çocukların firıncı rollerine girerek oyun yoluyla, hazır ve kolay tüketimin aslında zor aşamalardan geldiği konusunda fikir sahibi oldukları gözlenmiştir. Atölye sonunda çocuklara firıncı ne iş yapar? sorusu yöneltildiğinde çocukların verdikleri cevaplarla markete gelmeden önce hangi aşamalardan geçtiği konusunda bilgi sahibi oldukları gözlenmiştir. Çocukların daha çok hazır alınan yerleri, marketleri, pastaneleri bildikleri anlaşılmıştır.

9. Oturum: "Gastronomi ve mutfak sanatı mesleği hakkında fikir sahibi olur" kazanımına yönelik çocukların verdiği geri bildirimlere aşağıda yer verilmiştir. $\mathrm{Bu}$ oturumda çocukların “Gastronomi uzmanı nedir?” sorusuna verdikleri cevaplardan daha önce bu mesleği hiç duymadıkları ifade edilmiştir. Gerek medya gerek aile ve çevrede bu mesleği yeteri kadar tanıtan, anlatan kişilerin olmadığı, dolayısıyla da çoğu kişinin bu mesleği bilmediği, çocukların verdiği yanıtlardan da anlaşılmaktadır. Atölye başlarında çocukların daha çok aş̧̧ıları tanıdığı, atölye sonunda ise gastronomi uzmanı hakkında fikir sahibi oldukları sorulara verdikleri yanıtlardan anlaşılmaktadır. Çocukların önce aşçı olup krala pasta yapacaklarını duyduklarında pastalarını daha az özenle yaptıkları, ancak gastronomi uzmanı olduklarında tüm çocukların görselliğe ve sunuma özen gösterdikleri dikkat çekmiştir. Pastalarını yapıp süsledikten sonra "pastamız bitti” dedikleri ve önceden dağıtılan gümüş renkli tabakları kullanmadıkları gözlenmiştir, çocuklardan ikisi krala vereceklerini hatırlattıklarında ise çocukların tamamının pastalarını dikkatlice bozmadan tabakları kullandıkları gözlenmiştir. $\mathrm{Bu}$ atölyede gözlenen; toplum içindeki unvan ve statü etkisinin çocuklar üzerinde de fark edildiği ve çocukların yaptıkları ürünün kral tarafından beğenilip takdir görmesi için çaba sarf ettikleridir. Pasta yapımı esnasında kız çocukların pastaları daha estetik görünümlü iken erkek çocukların pastaları yine süslü ancak şekilleri birbirine benzerdir, buradan hareketle kız çocuklarının görselliği erkeklere oranla daha çok önemsedikleri kanısına varılmıştır. Çocuklar kendi yapmış oldukları pastaları korudukları gibi aynı şekilde arkadaşlarının pastalarını da özenle saklayarak onlara da sahip çıktılar, bozulmaması ve dökülmemesine son derece dikkat ettiler. Yaptıkları emeğe saygı duyup 
onu korudukları gözlenmiştir. Erkek çocuklar ellerine giydikleri eldivenden çabuk sıkılıp çıkarmak isterken kızlar pasta bitimine kadar eldivenle çalışmaya dikkat etmişlerdir.

10. Oturum: "Çilingir mesleği hakkında fikir sahibi olur." kazanımına yönelik çocukların verdiği geri bildirimlere aşağıda yer verilmiştir. Çocuklara sorulan sorulardan yola çıkıldığında hiçbir çocuğun çilingiri tanımadığı gözlenmiştir. İlk defa duyduklarını söylemişlerdir, çocukların daha çok kilitli kalma durumuyla karşılaştıklarında tamirciyi bildikleri anlaşılmıştır. Çocuklar, anahtarcının anahtarı satan kişiler olduğunu düşünmektedirler. Atölye esnasında kilitli kalan kralı kurtarmak için takım çantası ile gelen çilingir tüm çocukların dikkatini çekmiş, özellikle erkek çocukların takım çantasını kullanarak kilitli kalanı kurtarmak için istekli oldukları izlenmiştir. Kız çocuklarının ise atölye çalışmalarında daha çok kurtarılan olmayı tercih ettikleri gözlenmiştir. Atölye sonunda çocukların söylediklerinden ve sorulara verdikleri cevaplardan çilingir mesleği hakkında fikir sahibi oldukları anlaşılmıştır. Ayrıca veli görüşmeleri de bu sonucu destekler niteliktedir.

11. Oturum: "Apron görevlisi hakkında fikir sahibi olur” kazanımına yönelik çalışmalar neticesinde çocukların apron görevlisini ilk defa duydukları ve daha önce hiç bilmedikleri gözlenmiştir. Uçakların park ettiğini, onların da bir bekleme yeri olduğunu daha önce hiç düşünmediklerini, uçakları sadece pilotların uçurduğunu bildiklerini söylemişlerdir. "Arabalara park etmesi için yardım eden bazı kişiler vardır peki düşündünüz mü hiç acaba uçaklara park etmesi için kim yardım edebilir?" sorusu ile çocukların daha geniş düşünerek gördüklerinin arka planında bulunan çalışanların da olduğu hakkında fikir sahibi olmaları ve bu konuya kafa yormaları amaçlanır. Tüm çocuklar bu soruya cevap olarak pilot demiştir. Atölye çalışmasında çocuklar apron görevlisi rolüne girip uçakları park ettirip, park yerlerinin bakımını yapması, uçakların ne kadar süre bekleyeceğini form doldurarak apron amirliğine bildirmesi sonucunda bu meslek hakkında fikir sahibi olmuşlardır. Çocukların atölye sonrasında sorulan sorulara verdikleri cevaplarla ve yapmış oldukları resimlerde uçak kullanıp, elini kaldıran (uçağı park etmeye yardım eden) adam imgesi çizmeleri ile ayrıca yapılan veli görüşmelerinde bu meslek hakkında fikir sahibi oldukları olumlu dönütler alınarak görülmüştür.

12. Oturum: "Drama öğretmeni hakkında fikir sahibi olur "kazanımına yönelik çalışmalar sonucunda çocukların verdiği geri bildirimlere aşağıda yer verilmiştir. Çocukların atölye başında drama öğretmeni hakkında sadece "oyun oynatan, eğlendiren" tanımını yapmaları bu mesleği çok tanımadıklarını göstermiş̧ir. Atölye sonunda, şimdiye kadar geçen süreç içinde bir taraftan oyun oynarken diğer taraftan meslekleri öğrendiklerini, aslında her atölyede drama çalışması içinde olduklarını atölyenin sonunda fark etmişler, dolayısıyla drama öğretmeni mesleğini de yaşayarak, içinde bulunarak anlamış ve algılamışlardır. "Oyun yoluyla anlatan, rollere giren, düşündürüp, çözüm yolu üreten, yaşayarak, öğreten kimdir?” sorusuna çocukların drama öğretmeni cevabını verdikleri gözlenmiştir. Oturum sonunda sorulara verdikleri cevaplar ışığında, öğrendikleri ile drama öğretmeni arasında olumlu bağlantı kurdukları gözlenmiştir.

\section{Sonuç ve Öneriler}

Çalışma kapsamında planlanan meslekler hakkında çok az bilgisi olan ya da hiç bilgisi olmayan çocukların yaratıcı drama yöntemi ile uygulanmış atölyeler sonrasında hedeflenen meslekler hakkında fikir sahibi olduğu görülmüştür. Atölye çalışmaları sırasında çocukların tükettikleri gıdaların nerede üretildiğini bilmedikleri, sadece satın alınan yerler hakkında bilgi sahibi oldukları dikkat çekmiştir. 
Yaratıcı drama yönteminin kalıcı olarak öğrenme sağladığı bir çok alanda gözlenmiştir. Mesleklerin tanıtıldığı bu çalışmanın sonrasında velilerle yapılan görüşmelerde, yaratıcı drama yöntemi ile çocukların bilmedikleri ya da az bildikleri meslekler hakkında fikir sahibi oldukları ve bunları kalıcı olarak öğrendikleri ortaya çıkmıştır. Atölyeler sırasında tutulan öğretmen gözlem kayıtlarında, atölyelerin kazanımlarının çocuklar tarafından gösterildiği, böylece projenin amacına ulaşıldığ1 görülmüştür. Atölyeler esnasında çocukların mesleklere yönelik yaptığ1 resimlerde, çocukların meslek hakkında fikir sahibi oldukları ve özetle projenin hedeflerinin gerçekleştiği görülmüştür.

Her gün bir atölye uygulanması çocukların yaşları göz önünde bulundurularak planlanmıştır. Çocukların süreçsel drama yaklaşımı ile yapılandırılmış bir çalışma olarak ilk deneyimleridir. Süreçsel dramanın çocuklar üzerinde öğretme etkisinin büyük olduğu izlenmiştir. Liderin role girmesi ve mesleklere yönelik kıyafetler giymesi sınıfta merakı ve ilgiyi artırmıştır.

Projenin beş-altı yaş grubu çocuklara uygulanmasının lideri hedefe daha hızlı ve sorunsuz ulaştırılacağı düşünülmektedir. Dört yaş grubu çocukların meslekler hakkında fikir sahibi oldukları, ancak mesleklerin isimlerini hatırlamakta zorlandıkları gözlenmiştir. Ayrıca tanıtılması planlanan mesleğe ait materyallerin daha fazla olması, çocukların süreçte etkinliğinin fazla olmasını sağlayacağı düşünülmektedir. Yaratıcı drama yöntemi ile günümüzde varlığı sürdürülmeyen mesleklerin öğretilmesi için de kolaylıkla kullanılabilir.

\section{Kaynakça}

Adıgüzel, H. Ö. (2012). Eğitimde yaratıcı drama. Ankara: Naturel Yayınları.

Adıgüzel, H. Ö. (2006). Yaratıcı drama kavramı bileşenleri ve aşamaları. Yaratıcı Drama Dergisi, 1(1), 24.

Kaytez, N. ve Durualp, E. (2014). Türkiye'de okul öncesinde oyun ile ilgili yapılan lisans üstü tezlerin incelenmesi. Uluslararası Türk Eğitim Bilimleri Dergisi, 2(2).

Kuzgun, Y. (2002). Rehberlik ve psikolojik danışma (8.bs.). Ankara: ÖSYM Yayınları.

Kuzgun, Y. (2009). Meslek gelişimi ve danışmanlı̆̆ (3.bs.). Ankara: Nobel Yayınları.

Liben, L. S., Bigler, R.S. ve Krogh, H.R . (2001). Pink and blue collar joabs: Children's judgments of job aspirations in relation to sex of worker. Child Psychology, 79, 346-363.

Özgüven, İ.E. (2000). Çağdaş eğitimde psikolojik danışma ve rehberlik. Ankara: Sistem Ofset.

Öztürk, A. (2010). Okul öncesi eğitimde oyun. Ankara: Eğiten Kitap.

Rastgeldi, H. (2005). 6 yaş çocuklarının meslekleri tanıma durumlarının incelenmesi. Yayımlanmamış yüksek lisans tezi. Gazi Üniversitesi Eğitim Bilimleri Enstitüsü, Ankara.

San, İ. (1991). Eğitim öğretimde yaşayarak öğrenme yöntemi ve estetik süreç olarak yaratıcı drama. H. Ö. Adıgüzel (Ed.). 1985-1998 Yazılar içinde. Ankara: Naturel Yayınları.

Tan, H.(2000). Psikolojik danışma ve rehberlik hizmetleri. Ankara: Nobel yayınları.

Ulutaş, A. Okul öncesi dönemde drama ve oyunun önemi. Adlyaman Üniversitesi Sosyal Bilimler Enstitüsü Dergisi, 4(6), 232- 242.

Yazar, A. , Çelik M. ve Kök, M. (2007). Okul öncesi eğitimde yaratıcı dramanın çocuğun gelişim alanlarına etkisi, Atatürk Üniversitesi Kazım Karabekir Eğitim Fakültesi Dergisi, 6.

Yeşilyaprak, B. (2003). Eğitimde rehberlik hizmetleri. Ankara: Nobel Yayınları. 
